\title{
Improving Mathematical Communication Ability and Self Confidence of Junior High School Students Through Learning Transactional Reading Strategy
}

\author{
Ukan Suheri \\ IKIP Siliwangi \\ 09.08.24.ukry@gmail.com
}

\begin{abstract}
This study is a quasi experiment that aims to determine whether the achievement and improvement of students' mathematical communication skills and confidence of students who get the Learning Transactional Reading Strategy is better than the ordinary study reviewed overall and KAM categories. Alternative approach applied is Learning Transactional Reading Strategy. The research method used is quasi experimental method with the population of junior high school students in Bandung. While the sample is taken from class VII as much as two classes are randomly selected from 9 classes. Before doing the research the first test of prerequisite or Early Mathematical Ability (KAM) is done. At the beginning and end of the learning the two experimental and control classes were given a test and attitude questionnaire. The data collection in this research is in the form of test which contains 6 description questions for mathematical communication ability and 30 attitude questionnaires of student's self confidence.

The score data of each capability was analyzed by descriptive and inferential statistic using the difference test of two averages. Based on the results of the study, both the results of data analysis and hypothesis testing, the author concludes that the improvement of mathematical communication skills of students who get the learning transactional reading strategy is better than the improvement of students' communication skills learning using ordinary learning reviewed overall and KAM category is medium. While the self-confidence of students who get the learning transactional reading strategy is better than the students' self-confidence who get ordinary learning reviewed overall and categories of high, medium and low KAM.
\end{abstract}

Keywords: Communication, Self -Confidence, Learning Transactional Reading Strategy

\section{INTRODUCTION}

Mathematics is one of the important lessons in everyday life. The importance of learning mathematics can not be separated from its role in life, for example, various information and ideas can be communicated by the language of mathematics, as well as many problems that can be simplified and presented in the mathematical model. For example, trade problems can be presented in mathematical equations, matrices, and so on. Mathematics has a characteristic as a science that has an abstract object. Mathematics 
courses need to be given to all learners to equip them with logical, analytical, systematic, critical and creative thinking and cooperative skills. Such competence is necessary so that learners have the ability to acquire, manage and utilize information to survive in an everchanging, uncertain and competitive state. Math is therefore studied at all levels of education in the hope of discovering the ability and shaping the learners' personalities in line with future demands. In addition, the future competencies that students must achieve in the 2013 curriculum are the ability to communicate, think critically, the ability to be responsible citizens, understand and tolerant of different views and have broad interests. Based on the purpose of learning mathematics can be traced that learning mathematics certainly not only develop the mathematical ability but also the attitude of students to mathematics.

Communication skills required learners to be able to convey what is thought, put forward ideas and dealing with others. If learning is seen as a process that involves communication, then the interaction between learners and teachers and between learners and other learners is very important. However, communication opportunities arise not only because of interaction, but more important is the transactions between the people involved in them to construct meaning. In line with that, Baroody (Kadir, 2010: 31) says that there are at least two important reasons for the need to discover communication in learning mathematics. First, mathematics as an essential language, mathematics is not just a thinking tool, a tool for finding patterns, solving problems, or drawing conclusions, but math is also an invaluable tool for communicating ideas clearly, precisely and briefly. Second, mathematics is a social activity and also as a vehicle for interaction.

The process of learning mathematics also needs to consider the learning environment to ensure students' comfort, this can be done by showing a friendly and patient attitude in dealing with various problems faced by students, always trying to make students be free, and presenting mathematical material in a more concrete form. The aim is to discover students' interest in mathematics so that it is expected to foster selfconfidence in math skills.

Student self-confidence in teaching and learning process can be seen from active, creative, and innovative attitude and always actively involved in every learning activity. Students activeness will appear if the students master the concept well so as to solve the problems given by the teacher and able to develop his mindset, want to express ideas and others. Students can think and reason a mathematical problem and understand math problems so that they can solve the mathematical problem. A student's perspective on mathematical issues influences the mindset about the settlement.

Based on the reality in the field almost in every school found most of the students have low ability on materials that demand communication skills such as problems related to real objects, drawings and diagrams into mathematical ideas or vice versa as on the subject line, angle and figure. In fact, most students do not have curiosity so it will greatly affect the other affective side, such as self-confidence, learning independence, mathematical disposition and others. In addition to the above facts, encountered also interaction in learning only happened one direction that is from teacher as source of information and student as recipient of information. Students are not given many opportunities to actively participate in teaching and learning activities in the classroom, in other words learning is more teacher-centered, not students. Mathematics learning that is implemented today is oriented more to the outcome than the process.

Addressing the problems that arise in mathematics education, and hope to be achieved in learning mathematics, it is necessary innovative efforts to improve and 
improve the quality of learning mathematics through improvement of the learning process. transactional reading strategy (TRS) is one of the learning strategies that is expected to improve students' mathematical ability. In addition to the transactional reading strategy, there are other things that will be considered in learning, namely Mathematical Preliminary Ability (KAM). According Ismaimuza (2010), KAM students is the initial ability (student prior knowledge) that has been owned by students before the study was conducted.

Departing from the description above, the formulation of this research is whether the achievement and improvement of mathematical communication skills and self-confidence of students who get the Learning Transactional Reading Strategy is better than the ordinary study reviewed overall and KAM categories.

\section{RESEARCH METHOD}

This research is a research conducted with quasi-experimental method, this research aims to improve students' mathematical communication ability of selfconfidence through the application of Transactional reading strategy (TRS) learning. This research involves two classes namely experiment class and control class. The experimental class is a group of students whose learning uses transactional reading strategy, while the control class is a group of students whose learning use ordinary learning.

$\begin{array}{lcccc}\text { Class } & & \text { Pretest } & \text { Treatment } & \text { Postest } \\ \text { Eksperiment } & : & \mathrm{O} & \mathrm{X} & \mathrm{O} \\ & & --------------------------------------------- \\ \text { Controls } & : & \mathrm{O} & & \mathrm{O}\end{array}$

Information :

O: Pretes and postes the ability of mathematical communication, especially students' selfconfidence postes only

X: Transactional reading strategy (TRS)

Table 1. Research Design Patterns

\begin{tabular}{|c|c|c|c|c|}
\hline \multirow{4}{*}{ SUBJECT } & Class & Pretest & Treatment & Postes \\
\hline & & $\begin{array}{l}\text { Mathematical } \\
\text { communication test }\end{array}$ & \multirow[b]{2}{*}{$\begin{array}{l}\text { Learning } \\
\text { Transactional } \\
\text { Reading Strategy }\end{array}$} & $\begin{array}{l}\text { Mathematical } \\
\text { communication test }\end{array}$ \\
\hline & Experiment & 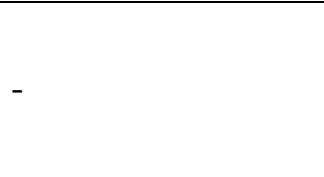 & & $\begin{array}{l}\text { Attitudes } \\
\text { questionnaire of } \\
\text { mathematical } \\
\text { confidence }\end{array}$ \\
\hline & Controls & $\begin{array}{l}\text { Mathematical } \\
\text { communication test }\end{array}$ & Ordinary learning & $\begin{array}{l}\text { Mathematical } \\
\text { communication test }\end{array}$ \\
\hline
\end{tabular}

This research was conducted from February 19, 2018 until May 29, 2018 in the even semester of the academic year 2017-2018 at SMPN 3 Bandung with the subject of research is the students of class VII with the number of 64 students consisting of 32 students of experimental class and 32 class students control.

The instruments used are 6 problems of mathematical communication skills and 30 attitude questionnaire of self-confidence. Sources of data are the results of pretest and postes the ability of mathematical communication and the scale of self-confidence. As 
well as Mathematical Preliminary Data (KAM). Data obtained from this research is processed by using microsoft excel2016 and statistic of IBM SPSS 24.

\section{RESULTS AND DISCUSSION}

Table 2. Descriptive Statistics of Communication Ability and Confidence Scores Overall Self and KAM Category

\begin{tabular}{|c|c|c|c|c|c|c|c|c|c|c|}
\hline & \multirow[t]{2}{*}{ KAM } & & \multicolumn{4}{|c|}{$\begin{array}{l}\text { Learning Transactional Reading } \\
\text { Strategy }\end{array}$} & \multicolumn{4}{|c|}{ Ordinary Learning } \\
\hline & & & $\mathrm{N}$ & Pretest & Postest & $N$-Gain & $\mathrm{N}$ & Pretest & Postest & N-Gain \\
\hline \multirow{11}{*}{ 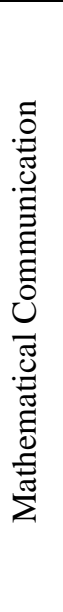 } & \multirow{2}{*}{ High } & $\bar{x}$ & \multirow{2}{*}{10} & 14.20 & 43.60 & 0.76 & \multirow{2}{*}{9} & 11.67 & 41.44 & 0.71 \\
\hline & & $\mathrm{s}$ & & 4.57 & 5.87 & 0.12 & & 2.55 & 5.55 & 0.12 \\
\hline & \multirow{2}{*}{ Medium } & $\bar{x}$ & \multirow{2}{*}{13} & 9.62 & 38.77 & 0.65 & \multirow{2}{*}{14} & 9.50 & 32.93 & 0.53 \\
\hline & & $\mathrm{s}$ & & 3.40 & 4.38 & 0.09 & & 1,56 & 4.89 & 0.11 \\
\hline & \multirow{2}{*}{ Low } & $\bar{x}$ & \multirow{2}{*}{9} & 6.89 & 25.89 & 0.39 & \multirow{2}{*}{9} & 7,67 & 20.78 & 0.29 \\
\hline & & $\mathrm{s}$ & & 1.69 & 8.08 & 0.15 & & 1,50 & 6.91 & 0.11 \\
\hline & \multirow{5}{*}{ Whole } & $\bar{x}$ & \multirow{5}{*}{32} & 10.28 & 36.66 & 0.61 & \multirow{5}{*}{32} & 9.59 & 31.91 & 0.51 \\
\hline & & $\mathrm{s}$ & & 4.44 & 9.24 & 0.19 & & 2.37 & 9.65 & 0.20 \\
\hline & & $\mathrm{L}$ & & 19.04 & 67.88 & & & 17.77 & 59.09 & \\
\hline & & $\mathrm{s}$ & & 4.31 & 9.57 & 0.20 & & 4.57 & 10.01 & 0.20 \\
\hline & & $\mathrm{L}$ & & 18.17 & 65.63 & & & 18.34 & 56.13 & \\
\hline \multirow{9}{*}{$\begin{array}{l}\stackrel{\overrightarrow{0}}{0} \\
\stackrel{0}{0} \\
\dot{0}\end{array}$} & \multirow{2}{*}{ High } & $\bar{x}$ & \multirow{2}{*}{10} & & 101.60 & & \multirow{2}{*}{9} & & 92.67 & \\
\hline & & $\mathrm{s}$ & & & 9.72 & & & & 11.45 & \\
\hline & \multirow{2}{*}{ Medium } & $\bar{x}$ & \multirow{2}{*}{13} & & 97,00 & & \multirow{2}{*}{14} & & 80.36 & \\
\hline & & $\mathrm{s}$ & & & 0.15 & & & & 11.00 & \\
\hline & \multirow{2}{*}{ Low } & $\bar{x}$ & \multirow{2}{*}{9} & & 88.67 & & \multirow{2}{*}{9} & & 81.11 & \\
\hline & & $\mathrm{s}$ & & & 10.30 & & & & 6.88 & \\
\hline & \multirow{3}{*}{ Whole } & $\bar{x}$ & \multirow{3}{*}{32} & & 96.09 & & \multirow{3}{*}{32} & & 84.03 & \\
\hline & & $\mathrm{s}$ & & & 10.64 & & & & 10.01 & \\
\hline & & $\mathrm{L}$ & & & 80.08 & & & & 70.03 & \\
\hline
\end{tabular}

SMI : Mathematical Communication $=54 ;$ Confident $=120 ; N$-Gain $=1$

Based on Table 2 it can be expressed that:

a) The average pretest of mathematical communication skills is viewed in its entirely and each category of KAM (low, medium, and high) in the TRS Learning class and regular learning class does not differ greatly. Acquisition of Pretes as a whole and each category of KAM (high, and medium) TRS learning classes are higher than ordinary learning classes with a difference of $0.69,2.53$ and 0.12 respectively. As for the pretest of students in low KAM category, the usual learning class is higher than the TRS learning class with the difference of 0.78 .

b) The average postes of mathematical communication ability are viewed as a whole and each category of KAM (high, medium, and low), TRS Learning class is higher than ordinary learning class by the difference of $4.75,2.16,5,84$, and 5.11 . The higher the KAM the higher the achievement score of the mathematical communication ability, it 
means that KAM plays a role in the achievement of the postes score of mathematical communication ability.

c) Average N-Gain mathematical communication capability viewed overall and each category of KAM (high, medium, and low), TRS learning class higher than ordinary learning classes with the difference of $0.10,0.09,0.12$, and 0.13 . This means improving students 'mathematical communication skills TRS learning classes better than the improvement of students' mathematical communication skills with ordinary learning.

d) Average postes of students' overall mathematical self-confidence score and each category of KAM (high, medium, and low) TRS learning classes are better than ordinary learning classes with an average difference of 12.06, 8.93, 16, 64, and 7.56. This means students 'confidence with the TRS learning is better than the students' self-confidence with the usual learning.

Results of data analysis:

1. Data score postes the ability of mathematical communication.

Table 3. Normality Tests Score Postes Result The ability of mathematical communication

\begin{tabular}{|c|c|c|c|c|c|c|}
\hline \multirow{2}{*}{ Class } & \multirow{2}{*}{ KAM } & \multicolumn{3}{|c|}{ Kolmogorov-Smirnov ${ }^{a}$} & \multirow{2}{*}{ Conclusion } & \multirow{2}{*}{ Note } \\
\hline & & Statistic & $D f$ & Sig. & & \\
\hline \multirow{4}{*}{ TRS Learning } & Whole & 0.116 & 32 & 0.200 & $\mathrm{H}_{0}$ accepted & Normal \\
\hline & High & 0.194 & 10 & 0.200 & $\mathrm{H}_{0}$ accepted & Normal \\
\hline & Medium & 0.171 & 13 & 0.200 & $\mathrm{H}_{0}$ accepted & Normal \\
\hline & Low & 0.210 & 9 & 0.200 & $\mathrm{H}_{0}$ accepted & Normal \\
\hline \multirow{4}{*}{$\begin{array}{l}\text { Ordinary } \\
\text { Learning }\end{array}$} & Whole & 0,081 & 32 & 0.200 & $\mathrm{H}_{0}$ accepted & Normal \\
\hline & High & 0.115 & 9 & 0.200 & $\mathrm{H}_{0}$ accepted & Normal \\
\hline & Medium & 0.225 & 14 & 0.052 & $\mathrm{H}_{0}$ accepted & Normal \\
\hline & Low & 0.200 & 9 & 0.200 & $\mathrm{H}_{0}$ accepted & Normal \\
\hline
\end{tabular}

Table 4. Homogenity Test Score Postes Result The ability of mathematical communication

\begin{tabular}{lccc}
\hline \multirow{2}{*}{ KAM } & \multicolumn{3}{c}{ Homogenity Test } \\
\cline { 2 - 4 } & $\mathbf{F}$ & Sig. & Note \\
\hline Whole & 0.092 & 0.763 & $\mathrm{H}_{0}$ accepted \\
\hline High & 0.193 & 0.666 & $\mathrm{H}_{0}$ accepted \\
\hline Medium & 0.221 & 0.643 & $\mathrm{H}_{0}$ accepted \\
\hline Low & 0.055 & 0.818 & $\mathrm{H}_{0}$ accepted \\
\hline
\end{tabular}


Table 5. Difference Test of Two Scores Postes Result The ability of mathematical communication

\begin{tabular}{lcc}
\hline \multirow{2}{*}{ KAM } & \multicolumn{2}{c}{ Uji t } \\
\cline { 2 - 3 } & Asymp.Sig.(2-tailed) & Note \\
\hline Whole & 0.049 & $\mathrm{H}_{0}$ rejected \\
\hline High & 0.424 & $\mathrm{H}_{0}$ accepted \\
\hline Medium & 0.003 & $\mathrm{H}_{0}$ rejected \\
\hline Low & 0.169 & $\mathrm{H}_{0}$ accepted \\
\hline
\end{tabular}

Table 3 shows the posttest score data of overall mathematical communication skills and by KAM category in the experimental class and the normal distributed control class, so that it is followed by the homogeneity test seen in Table 4, all posttest data of mathematical communication ability in both homogeny classes. To find out the difference was significantly tested by parametric test of $t$ test, the result showed in Table 5 that there was a significant difference in mathematical communication ability of students who received TRS learning with students who received ordinary learning overall and medium KAM category. While in high and low KAM category did not differ significantly.

It concludes that the achievement of mathematical communication ability of students who get the TRS learning is better than the students who get overall ordinary learning and medium KAM category.

2. N-Gain score data of mathematical communication ability

Table 6. Recapitulation of N-Gain of Mathematical Communication Ability

\begin{tabular}{|c|c|c|c|c|c|}
\hline \multirow{2}{*}{ Class } & \multirow{2}{*}{ Statistic } & \multicolumn{3}{|c|}{ KAM } & \multirow{2}{*}{ Whole } \\
\hline & & High & Medium & Low & \\
\hline TRS & $\mathrm{N}$ & 10 & 13 & 9 & 32 \\
\hline \multirow[t]{2}{*}{ Learning } & $\bar{x}$ & 0.74 & 0.66 & 0.40 & 0.61 \\
\hline & Criteria & High & Medium & Medium & Medium \\
\hline Ordinary & $\mathrm{N}$ & 9 & 14 & 9 & 32 \\
\hline \multirow[t]{2}{*}{ Learning } & $\bar{x}$ & 0.71 & 0.53 & 0.27 & 0.51 \\
\hline & Criteria & High & Medium & Low & Medium \\
\hline
\end{tabular}


Table 7. Normality Test Results N-Gain Score Ability of mathematical communication

\begin{tabular}{|c|c|c|c|c|c|c|}
\hline \multirow{2}{*}{ Class } & \multirow{2}{*}{ KAM } & \multicolumn{3}{|c|}{ Kolmogorov-Smirnov ${ }^{a}$} & \multirow{2}{*}{ Conclusion } & \multirow{2}{*}{ Information } \\
\hline & & Statistic & $D f$ & Sig & & \\
\hline \multirow{4}{*}{$\begin{array}{l}\text { TRS } \\
\text { Learning }\end{array}$} & Whole & 0.920 & 32 & 0,200 & $\mathrm{H}_{0}$ accepted & Normal \\
\hline & High & 0.162 & 10 & 0.200 & $\mathrm{H}_{0}$ accepted & Normal \\
\hline & Medium & 0.140 & 13 & 0.200 & $\mathrm{H}_{0}$ accepted & Normal \\
\hline & Low & 0.217 & 9 & 0.200 & $\mathrm{H}_{0}$ accepted & Normal \\
\hline \multirow{4}{*}{$\begin{array}{l}\text { Ordinary } \\
\text { Learning }\end{array}$} & Whole & 0.110 & 32 & 0.200 & $\mathrm{H}_{0}$ accepted & Normal \\
\hline & High & 0.122 & 9 & 0.200 & $\mathrm{H}_{0}$ accepted & Normal \\
\hline & Medium & 0.191 & 14 & 0.280 & $\mathrm{H}_{0}$ rejected & Abnormal \\
\hline & Low & 0.670 & 9 & 0,188 & $\mathrm{H}_{0}$ accepted & Normal \\
\hline
\end{tabular}

N-Gain score data of mathematical communication ability in TRS learning class as a whole and based on high, medium and low KAM categories normally distributed. Whereas in normal learning class normal distribution normal and high KAM low category, abnormal distribution in medium category. Based on the data in Table 7 above then continued homogeneity test and parametric test the mean difference for overall data and high and low KAM categories as well as direct non-parametric test of Mann-Whitney $\mathrm{U}$. for medium category KAM data.

Table 8. Homogeneity Test Results and Two-Difference Difference Test N-Gain Score Ability of mathematical communication

\begin{tabular}{|c|c|c|c|c|c|c|}
\hline \multirow[t]{3}{*}{ KAM } & \multicolumn{6}{|c|}{ Statistic } \\
\hline & \multicolumn{3}{|c|}{ F test } & \multicolumn{3}{|c|}{ T test } \\
\hline & $\mathbf{F}$ & Sig. & Information & $\begin{array}{c}\text { Asymp. } \\
\text { Sig.(2-tailed) }\end{array}$ & $\begin{array}{c}\text { Asymp. } \\
\text { Sig.(1-tailed) }\end{array}$ & Information \\
\hline Whole & 0.055 & 0.815 & $\mathrm{H}_{0}$ accepted & 0.039 & 0.019 & $\mathrm{H}_{0}$ accepted \\
\hline High & 0.285 & 0.600 & $\mathrm{H}_{0}$ accepted & 0.557 & 0.279 & $\mathrm{H}_{0}$ rejected \\
\hline Medium & \multicolumn{3}{|c|}{ Uji Mann-Whitney U. } & 0.005 & 0.003 & $\mathrm{H}_{0}$ accepted \\
\hline Low & 0.135 & 0.718 & $\mathrm{H}_{0}$ accepted & 0.137 & 0.067 & $\mathrm{H}_{0}$ rejected \\
\hline
\end{tabular}

From Table 8 we get overall N-Gain score data and high and low homogeneous KAM categories, so that it is directly followed by parametric test of $t$ test. Results from the mean difference test of both $t$ test and non-parametric test of Mann-Whitney $U$. indicated that the improvement of mathematical communication ability of students who 
received TRS learning was significantly higher than that of students who received overall ordinary learning and medium KAM category. While in high and low KAM category did not differ significantly.

3. Data on the scale of students' self-confidence

Table 9. Test Result of Normality Test Self Confidence score

\begin{tabular}{|c|c|c|c|c|c|c|}
\hline \multirow{2}{*}{ Class } & \multirow{2}{*}{ KAM } & \multicolumn{3}{|c|}{ Kolmogorov-Smirnov ${ }^{a}$} & \multirow{2}{*}{ Conclusion } & \multirow{2}{*}{ Information } \\
\hline & & Statistic & $d f$ & Sig. & & \\
\hline \multirow{4}{*}{$\begin{array}{l}\text { TRS } \\
\text { Learning }\end{array}$} & Whole & 0.115 & 32 & 0.200 & $\mathrm{H}_{0}$ accepted & Normal \\
\hline & High & 0.237 & 10 & 0.119 & $\mathrm{H}_{0}$ accepted & Normal \\
\hline & Medium & 0.159 & 13 & 0.200 & $\mathrm{H}_{0}$ accepted & Normal \\
\hline & Low & 0.216 & 9 & 0.200 & $\mathrm{H}_{0}$ accepted & Normal \\
\hline \multirow{4}{*}{$\begin{array}{l}\text { Ordinary } \\
\text { Learning }\end{array}$} & Whole & 0.084 & 32 & 0.200 & $\mathrm{H}_{0}$ accepted & Normal \\
\hline & High & 0.103 & 9 & 0.200 & $\mathrm{H}_{0}$ accepted & Normal \\
\hline & Medium & 0.156 & 14 & 0.200 & $\mathrm{H}_{0}$ accepted & Normal \\
\hline & Low & 0.216 & 9 & 0.200 & $\mathrm{H}_{0}$ accepted & Normal \\
\hline
\end{tabular}

Table 10. Homogeneity Test Results Scale of Self Confidence

\begin{tabular}{lcccl}
\hline \multicolumn{1}{c}{ KAM } & $\mathbf{F}$ & Sig & Conclusion & Information \\
\hline Whole & 0.025 & 0.874 & $\mathrm{H}_{0}$ accepted & Homogeneous \\
\hline High & 0.144 & 0.709 & $\mathrm{H}_{0}$ accepted & Homogeneous \\
\hline Medium & 0.043 & 0.838 & $\mathrm{H}_{0}$ accepted & Homogeneous \\
\hline Low & 2.457 & 0.137 & $\mathrm{H}_{0}$ accepted & Homogeneous \\
\hline
\end{tabular}

Based on Table 9 and Table 10 the data on students' overall confidence attitude questionnaire and KAM categories are normal and homogeneous distributed. Furthermore, parametric test of average difference or $t$ test.

Table 11. Difference Tests of Two Average Score Attitude Questionnaire Result Confidence Based on Overall Student.

\begin{tabular}{ccccc}
\hline \multicolumn{4}{c}{ Statistic } & \multirow{2}{*}{ Conclusion } \\
\hline $\boldsymbol{T}$ & $\boldsymbol{D} \boldsymbol{f}$ & Sig. (2-tailed) & Sig. (1-tailed) & \\
\hline 4.402 & 62 & 0.000 & 0.000 & $\mathrm{H}_{0}$ rejected \\
\hline
\end{tabular}

Table 11 shows the results of the difference test scores on the average score of students 'self-confidence score and obtained sig. (1-tailed) $<0.05$ means that the self-confidence of students who get TRS learning is better than the students' self-confidence that gets the usual learning overall. 
Tabel 12. Test Results Difference Two Scores Average Score Self Confidence Based on Each KAM Category

\begin{tabular}{|c|c|c|c|c|c|}
\hline \multirow{2}{*}{$\begin{array}{c}\text { KAM } \\
\text { Category }\end{array}$} & \multicolumn{4}{|c|}{ Statistic } & \multirow{2}{*}{ Conclusion } \\
\hline & $T$ & $d f$ & Sig. (2-tailed) & Sig. (1-tailed) & \\
\hline High & 1.840 & 17 & 0.083 & 0.042 & $\mathrm{H}_{0}$ rejected \\
\hline Medium & 4.256 & 25 & 0.000 & 0.000 & $\mathrm{H}_{0}$ rejected \\
\hline Low & 1.830 & & 0.086 & 0.043 & $\mathrm{H}_{0}$ rejected \\
\hline
\end{tabular}

Table 12 shows the results of the difference test scores on the average score of students 'self-confidence score and obtained sig. (1-tailed) $<0,05$ means that the self-confidence of students who get TRS learning is better than the students' self-confidence based on high KAM category, low , and medium.

\section{CONCLUSION}

The average score of the students on postes of mathematical communication ability and the higher the scale of self-esteem attitude in terms of the KAM category the higher the average score of mathematical communication ability and students' selfconfidence. This means that KAM plays a role in the achievement of students' mathematical communication skills and confidence. The implications prior to the start of new material learning need to be checked and consolidated before the students' prerequisite materials.

Achievement of students' mathematical communication skills of TRS learning class on a moderate level, while achieving mathematical communication ability in ordinary class at low level. Achievement of mathematical communication ability of students who receive TRS learning is better than students who received ordinary learning viewed from the overall data and KAM category being.

Improved mathematical communication skills of students who received TRS learning better than students who received rordinary learning viewed from the data as a whole and KAM category was at the level of significance 5\%. The increase is good in the class that gets TRS learning or ordinary learning is at a moderate level.

\section{REFERENCES}

Atika Rahmawati, 2016. Peningkatan Kemampuan Komunikasi dan Pemecahan Masalah Matematika Melalui Strategi Thing Talk Write, 2016

Baroody, A. (1998). Fostering children's mathematical power. New Jersey: Lawrence Erlbaum.

Hakim, T. (2002). Mengatasi Rasa Tidak Percaya Diri. Jakarta : Puspa Swara.

Ismaimuza, D. (2010). Pengaruh pembelajaran berbasis masalah dengan strategi konflik kognitif terhadap kemampuan berpikir kritis matematis dan sikap siswa SMP. Jurnal Pendidikan Matematika. Vol. 4 (1). 
National Cuncil of Teacher of Mathematics. (2000). Principles and standards for school mathematics. Reston, VA: NCTM.

Rina Aristiani, 2016. Meningkatkan Percaya Diri Siswa Melalui Layanan Informasi Berbantuan Audisionala, Juli-Desember 2016

Soemarmo, U. (2013). Berpikir dan disposisi matematik serta pembelajarannya. Bandung: Jurdikmat FPMIPA-UPI.

Surya, H. (2010). Rahasia membuat Anak Cerdas dan Manusia Unggul. Jakarta : PT. Elexmedia Komputindo.

Turmudi (2008). Landasan filsafat dan teori pembelajaran matematika: paradigma eksploratif dan investigatif. Jakarta: leuser Cita Pustaka. 